\title{
Optimasi Perolehan Bioetanol dari Kulit Nanas (Ananas cosmosus) dengan Penambahan Urea, Variasi Konsentrasi Inokulasi Starter dan Waktu Fermentasi
}

\author{
NOVI FITRIA ${ }^{1}$, EVA LINDASARI ${ }^{1}$
}

1. Sekolah Tinggi Analis Bakti Bandung, Jl. Padasuka Atas 233 Bandung, 40192 novi.fitria@staba.ac.id

\begin{abstract}
ABSTRAK
Bioetanol dapat dibuat dari bahan yang mengandung karbohidrat melalui proses fermentasi. Kulit nanas mengandung karbohidrat jenis fruktosa dan sukrosa dengan bantuan ragi karbohidrat tersebut akan diubah menjadi bioetanol melalui proses fermentasi. Pada penelitian ini, untuk memperoleh kadar bioetanol yang optimal dilakukan eksperimen yaitu dengan menambahkan urea sebanyak 5 gram dan variasi konsentrasi inokulasi starter 1\%, 1,5\%, 2\% dan 2,5\% dengan waktu fermentasi selama 24 jam, 48 jam, 72 jam dan 96 jam pada suhu $30^{\circ} \mathrm{C}$ melalui dua perlakuan yaitu melalui proses pemutaran dan tanpa melalui proses pemutaran. Hasil menunjukkan bahwa perolehan bioetanol yang optimum sebanyak $28,05 \%$ pada penambahan inokulasi starter $1,5 \%$ dengan waktu fermentasi 96 jam, pH 5 dan tanpa pemutaran. Limbah kulit nanas dapat dimanfaatkan untuk menghasilkan energi yang ramah lingkungan berupa bioetanol.
\end{abstract}

Kata kunci: bioetanol, inokulasi starter, fermentasi, limbah kulit nanas.

\begin{abstract}
Bioethanol can be made from materials containing carbohydrates through the fermentation process. Pineapple skin contains fructose and sucrose type carbohydrates with the help of yeast carbohydrates will be converted into bioethanol through the fermentation process. In this study, to obtain optimal bioethanol levels, an experiment was carried out by adding 5 grams of urea and variations in the concentration of starter inoculations of $1 \%, 1.5 \%, 2 \%$ and $2.5 \%$ with fermentation time for 24 hours, 48 hours, 72 hours and 96 hours at a temperature of $30^{\circ} \mathrm{C}$ through two treatments, with and without shaking process. The results showed that the optimum bioethanol acquisition was $28.05 \%$ on the addition of 1.5\% starter inoculation with 96 hours fermentation time, $\mathrm{pH} 5$ and without shaking process
\end{abstract}

Keywords: bioethanol, starter inoculation, fermentation, pineapple skin waste. 


\section{PENDAHULUAN}

Indonesia tercatat sebagai produksi buah nanas nomor tiga di dunia, sehingga memiliki potensi timbulan fruit waste berupa kulit nanas yang sangat tinggi. Dari satu buah nanas, sebanyak $76,36 \%$ dapat dimanfaatkan/dikonsumsi sedangkan sisanya dibuang sebagai limbah. Kulit nanas merupakan fruit waste yang dapat menghasilkan bioetanol karena mengandung $86,70-81,72 \%$ air, 1,66\%-20,87\% serat kasar, 10,54-17,53\% karbohidrat, 0,69-4,41\% protein, 0,02 \% lemak, 0,48\% abu dan 13,65\% gula reduksi (Ahmad \& Antonus, 2010; Riza, 2016). Bioetanol dapat dibuat dari bahan yang mengandung karbohidrat atau gula sederhana dan bahan berserat melalui proses fermentasi (Azizah dkk, 2012). Lama fermentasi dipengaruhi oleh faktor-faktor yang secara langsung maupun tidak langsung berpengaruh terhadap proses fermentasi seperti substrat, suhu, $\mathrm{pH}$, oksigen dan mikroba yang digunakan (Azizah dkk, 2012; Nasrun dkk, 2015).

Penelitian mengenai perolehan bioetanol dengan pemanfaatan buah dan kulit nanas telah banyak dilakukan sebelumnya dan menunjukkan hasil yang berbeda-beda. Sebagai contoh penelitian yang dilakukan oleh Ahmad \& Antonius (2010) menyatakan bahwa waktu optimum untuk fermentasi pembuatan bioetanol dari kulit nanas dengan menggunakan yeast Saccharomyces cereviceae adalah selama 3 hari dengan kadar bioetanol yang diperoleh sebesar $15,45 \%$. Selanjutnya penelitian yang dilakukan oleh Setyawati \& Rahman (2011) dengan memvariasikan massa Saccharomyces cereviceae sebanyak 20 gram, 30 gram dan 40 gram yang di fermentasi selama 2, 4, 6, 8, dan 10 hari menyatakan bahwa kadar bioetanol tertinggi diperoleh pada penambahan Saccharomyces cereviceae sebanyak 30 gram dan waktu fermentasi selama 10 hari sebesar 3,965\%. Penelitian yang lain dilakukan oleh Azizah dkk, (2012) menggunakan whey dengan substitusi kulit nanas kemudian difermentasi dengan 50 gram ragi roti (Saccharomyces cereviceae) selama 12, 24, 36, 48 dan 60 jam menyatakan bahwa lamanya waktu fermentasi tidak berpengaruh dalam meningkatkan kadar bioetanol tetapi berpengaruh dalam menurunkan nilai $\mathrm{pH}$. Kadar bioetanol yang diperoleh selama fermentasi 60 jam berkisar antara 1,21 - 2,25\%. Sedangkan menurut penelitian yang dilakukan oleh Mandary dkk (2012) dengan menggunakan enzim selulase dan yeast perolehan bioetanol dalam kulit pisang ambon 2009 Saccharomyces cereviceae dengan proses Simultaneous Sacharification and Fermentation (SSF) menyatakan bahwa penambahan enzim selulase dapat mempengaruhi kadar bioetanol yang diperoleh, semakin banyak enzim selulase yang ditambahkan maka kadar bioetanol yang dihasilkan semakin besar karena semakin banyak glukosa dikonversi menjadi bioetanol dengan kadar bioetanol tertinggi dihasilkan pada hari ke 3 karena waktu terbaik Saccharomyces cereviceae bekerja mengubah glukosa menjadi bioetanol adalah 3 hari.

Beberapa penelitian menggunakan penambahan urea sebagai sumber nitrogen yang bertujuan untuk membantu meningkatkan produksi bioetanol telah dilakukan. Sebagaimana penelitian yang telah dilakukan sebelumnya oleh Najah (2009) menyatakan bahwa kadar bioetanol tertinggi dari kulit pisang ambon kuning diperoleh setelah fermentasi 5 hari dengan penambahan nitrogen $7 \%$ yaitu sebesar 2,324\% (v/v). Sedangkan kadar bioetanol terendah yaitu $0,423 \%(\mathrm{v} / \mathrm{v})$ terjadi pada penambahan nitrogen $0 \%$ dan waktu fermentasi selama 9 hari. Penelitian yang lain dilakukan oleh Ahmad dan Antonius (2010) dengan menggunakan 400 gram kulit nanas, 8 gram yeast dan menambahkan 4 gram urea menghasilkan kadar bioetanol sebanyak $15,45 \%$ (b/b) dengan waktu fermentasi selama 3 hari. Berikutnya penelitian yang dilakukan oleh Apriani (2015) menyatakan bahwa penambahan Urea dan NPK dengan masing-masing kadar 0,3 gram Urea dan 0,2 gram NPK dalam menghasilkan volume bioetanol sebanyak $13,8 \mathrm{~mL}$ dan kadar bioetanol sebesar $2,37 \%$. 
Sedangkan berdasarkan hasil uji pendahuluan, digunakan starter yang terdiri dari glukosa 10\%, 6 gram urea dan 50 gram ragi roti (Saccharomycess cereviciae) yang diinokulasikan sebanyak $1 \%$ ke dalam substrat fermentasi sehingga diperoleh kadar bioetanol sebesar $4,03 \%$ dengan waktu fermentasi selama 36 jam. Untuk mengetahui perolehan kadar bioetanol yang paling optimal maka dalam penelitian ini pada proses fermentasi dilakukan dengan dua perlakuan yaitu melalui proses pemutaran dan tanpa melalui proses pemutaran. Dari berbagai penelitian yang telah dijelaskan menunjukkan bahwa semakin lama waktu fermentasi dan semakin banyak ragi yang digunakan tidak menjamin kadar bioetanol yang dihasilkan semakin meningkat kadar bioetanolnya. Bioetanol sebagai bahan bakar alternatif mempunyai kelebihan selain ramah lingkungan dan sifatnya yang terbarukan, penggunaannya sebagai campuran BBM terbukti dapat mengurangi emisi karbon monoksida hingga $18 \%$ dan asap lainnya dari kendaraan (Loupatty, 2014).

\section{METODOLOGI}

\subsection{Jenis dan Desain Penelitian}

Jenis penelitian yang digunakan adalah True Experiment. Hakikat penelitian eksperimen adalah meneliti pengaruh perlakuan terhadap perilaku yang timbul sebagai akibat perlakuan sebagai metode sistematis guna membangun hubungan yang mengandung fenomena sebab akibat (causal-effect relationship) untuk mencari pengaruh perlakuan tertentu terhadap yang lain dalam kondisi yang terkendalikan (Sugiyono, 2010). Desain penelitian tersedia pada Tabel 1.

Tabel 1. Desain Penelitian

\begin{tabular}{|c|c|c|c|}
\hline Kelompok & Material & Perlakuan & Post test \\
\hline Eksperimen & $\begin{array}{l}\text { - Limbah kulit } \\
\text { nanas } \\
\text { - Inokulasi } \\
\text { starter } \\
\text { - Penetapan } \\
\text { kondisi pH } 4-5 \\
\text { dan suhu } 30^{\circ} \mathrm{C}\end{array}$ & $\begin{array}{ll}\text { - } & \text { Variasi Inokulasi } \\
& \text { Starter (1\%; 1,5\%; } \\
2 \% ; 2,5 \% \\
\text { - } & \text { Variasi Waktu } \\
& \text { Fermentasi (24 jam, } \\
& 48 \text { jam, } 72 \text { jam dan } 96 \\
\text { jam) } \\
\text { - Dengan dan Tanpa } \\
\text { Pemutaran } \\
\text { - Pemurnian bioetanol } \\
\text { dengan destilasi }\end{array}$ & Diukur kadar bioetanol \\
\hline Kontrol & $\begin{array}{l}\text { - Limbah kulit } \\
\text { nanas } \\
\text { - Inokulasi } \\
\text { starter } \\
\text { - Penetapan } \\
\text { kondisi pH 4-5 } \\
\text { dan suhu } 30^{\circ} \mathrm{C}\end{array}$ & $\begin{array}{l}\text { - } \\
\text { Substrat fermentasi } \\
\text { ditambahkan inokulasi } \\
\text { starter } 1 \% \text { dengan } \\
\text { tanpa pemutaran dan } \\
\text { variasi waktu } \\
\text { fermentasi ( } 24 \text { jam, } 48 \\
\text { jam, } 72 \text { jam dan } 96 \\
\text { jam) } \\
\text { Permurnian bioetanol } \\
\text { dengan destilasi }\end{array}$ & Diukur kadar bioetanol \\
\hline
\end{tabular}


Untuk menentukan jumlah pengulangan yang harus dilakukan dalam penelitian ini, maka dapat digunakan rumus Federer (1977) yaitu : $(\mathrm{n}-1)(\mathrm{t}-1) \geq 15$, dimana t adalah treatment (perlakuan), dalam hal ini ada 32 perlakuan. Hasil perhitungan replikasi adalah $\geq 2$ sehingga penelitian ini melakukan pengulangan sebanyak 3 kali pada setiap perlakuannya.

\subsection{Alat dan Bahan}

Alat-alat yang digunakan adalah bunsen, kaki tiga, kasa asbes, labu leher tiga $500 \mathrm{~mL}$, termometer, pendingin, erlenmeyer $250 \mathrm{~mL}$, pipet volume $10 \mathrm{~mL}$, labu takar $50 \mathrm{~mL}$, gelas ukur $1000 \mathrm{~mL}$, gelas beaker $500 \mathrm{~mL}$, corong kaca, botol semprot, pipet tetes, gelas arloji, pengaduk kaca, blender, pisau, baskom, botol kaca, neraca teknis, neraca analitik, piknometer, $\mathrm{pH}$ meter. Sedangkan bahan-bahan yang digunakan adalah kulit nanas, ragi (Saccharomyces cereviceae), aquadest, glukosa, urea, larutan luff, $\mathrm{Na}_{2} \mathrm{~S}_{2} \mathrm{O}_{3} 0,1 \mathrm{~N}, \mathrm{~K}_{2} \mathrm{Cr}_{2} \mathrm{O}_{7}$ p.a, $\mathrm{KI}, \mathrm{H}_{2} \mathrm{SO}_{4}$ dan amilum.

\subsection{Prinsip}

Pada fermentasi anaerob, zat-zat organik dikatabolisme tanpa kehadiran oksigen yang berarti tidak adanya akseptor elektron eksternal melainkan melalui keseimbangan reaksi oksidasi-reduksi internal (Putra, 2017). Produk dihasilkan selama proses penerimaan elektron yang dilepaskan saat pemecahan zat-zat organik. Oleh karenanya zat-zat organik tersebut berperan sebagai akseptor dan donor elektron. Pada fermentasi, substrat hanya dioksidasi sebagian dan oleh karena itu hanya sedikit energi yang bisa dihasilkan. Glukosa sebagai substrat akan melepaskan elektron saat dirubah menjadi piruvat, namun elektron tersebut akan diambil piruvat untuk menjadi etanol (Prametha \& Legowo, 2013). Proses fermentasi dilakukan oleh mikroorganisme jenis ragi roti (Saccharomyces cereviceae) dimana Saccharomyces cereviceae memetabolisme glukosa membentuk asam piruvat melalui jalur Embden Meyerhof-Parnas. Asam piruvat selanjutnya mengalami reaksi dekarboksilasi menjadi asetaldehida dan mengalami reaksi dehidrogenasi menjadi bioetanol. Bioetanol yang dihasilkan kemudian di destilasi sehingga dapat dipisahkan antara etanol dan air (Rahman \& Setyawati, 2012).

\subsection{Prosedur Kerja}

Prosedur kerja yang dilakukan terdiri dari : (1) pembuatan substrat fermentasi yaitu $500 \mathrm{~g}$ kulit nanas $+1000 \mathrm{~mL}$ aquadest (1:2) yang diblender halus dan kemudian disaring untuk diambil filtratnya, lalu dipasteurisasi $70^{\circ} \mathrm{C}$ selama 15 menit dan didinginkan; (2) pembuatan starter yaitu homogenkan glukosa $10 \%+5 \mathrm{~g}$ urea dan $10 \mathrm{~g}$ ragi (Saccharomyces cereviceae) kemudian diinkubasi selama 1 malam pada suhu $30^{\circ} \mathrm{C}$; (3) menginokulasikan starter ke dalam substrat fermentasi dengan variasi konsentrasi $1 \%, 1,5 \%, 2 \%$ dan 2,5\% dimana $1 \%$ starter setara dengan $10 \mathrm{~mL}$; (4) substrat fermentasi yang telah diberikan inokulasi starter diberi perlakuan dengan dan tanpa pemutaran, pemutaran dilakukan dengan magnetic stirer, (5) kadar bioetanol diperiksa pada waktu 24 jam, 48 jam, 72 jam dan 96 jam; (5) pemurnian bioetanol dengan proses destilasi; (6) mengukur berat jenis bioetanol dengan menggunakan piknometer; (7) analisis data menggunakan ANOVA dan korelasi pearson dengan SPSS v.25. Berikut adalah rumus perhitungan berat jenis larutan kemudian dikonversikan ke dalam tabel konversi BJ alkohol :

$$
\rho \text { destilat }=\frac{(c-a) \operatorname{gram}}{(b-a) \operatorname{gram}}
$$

Dimana : (a) menimbang piknometer kosong, harus bersih dan kering; (b) menimbang piknometer yang telah diisi aquades; (c) menimbang berat piknometer yang telah destilat 
dan $\rho$ destilat $=$ menghitung berat jenis larutan kemudian dikonversikan ke dalam tabel konversi BJ alkohol. Disimulasikan perhitungan berat jenis jika diketahui $a=26,0135 \mathrm{~g} ; \mathrm{b}=$ $35,6564 \mathrm{~g}$ dan $\mathrm{c}=35,5045 \mathrm{~g}$ maka

$$
\rho \text { destilat }=\frac{(35,5045-26,0135) \mathrm{gram}}{(35,6564-26,0135) \mathrm{gram}}
$$

$\rho$ destilat $=0,9842$ setara dengan kadar bioetanol $12,02 \%$

\section{ISI (HASIL DAN PEMBAHASAN)}

Berdasarkan hasil penelitian, diperoleh data rerata nilai kadar bioetanol dengan waktu fermentasi selama 24 jam, 48 jam, 72 jam dan 96 jam dari setiap variasi konsentrasi inokulasi starter melalui proses pemutaran (P) dan tanpa melalui proses pemutaran (TP) dengan tiga kali pengulangan disajikan pada Tabel 2 .

Tabel 2. Kadar Bioetanol

\begin{tabular}{|c|c|c|c|c|c|}
\hline \multirow{2}{*}{$\begin{array}{c}\text { Konsentrasi } \\
\text { inokulasi } \\
\text { starter }\end{array}$} & \multirow{2}{*}{$\begin{array}{c}\text { Waktu } \\
\text { Fermentasi } \\
\text { (Jam) }\end{array}$} & \multicolumn{2}{|c|}{$\begin{array}{c}\text { Rata-rata Berat } \\
\text { Jenis }\end{array}$} & \multicolumn{2}{|c|}{$\begin{array}{l}\text { Rata-rata Kadar } \\
\text { Bioetanol }(\% \mathrm{~V} / \mathrm{V})\end{array}$} \\
\hline & & $P$ & TP & $P$ & TP \\
\hline \multirow[t]{4}{*}{$1 \%$} & 24 & 0,9959 & 0,9780 & 2,72 & 17,60 \\
\hline & 48 & 0,9860 & 0,9786 & 10,42 & 17,54 \\
\hline & 72 & 0,9849 & 0,9787 & 11,75 & 17,53 \\
\hline & 96 & 0,9933 & 0,9862 & 4,82 & 10,42 \\
\hline \multirow[t]{4}{*}{$1,5 \%$} & 24 & 0,9904 & 0,9850 & 2,02 & 11,22 \\
\hline & 48 & 0,9954 & 0,9789 & 3,42 & 17,63 \\
\hline & 72 & 0,9904 & 0,9798 & 7,12 & 16,53 \\
\hline & 96 & 0,9902 & 0,9669 & 7,12 & 28,05 \\
\hline \multirow[t]{4}{*}{$2 \%$} & 24 & 0,9922 & 0,9841 & 5,62 & 12,02 \\
\hline & 48 & 0,9975 & 0,9828 & 2,02 & 13,82 \\
\hline & 72 & 0,9963 & 0,9820 & 2,72 & 13,82 \\
\hline & 96 & 0,9972 & 0,9769 & 2,02 & 19,13 \\
\hline \multirow[t]{4}{*}{$2,5 \%$} & 24 & 0,9971 & 0,9844 & 2,02 & 12,02 \\
\hline & 48 & 0,9968 & 0,9863 & 2,72 & 10,42 \\
\hline & 72 & 0,9870 & 0,9803 & 9,82 & 15,73 \\
\hline & 96 & 0,9920 & 0,9813 & 5,88 & 14,82 \\
\hline
\end{tabular}

Keterangan : $\mathrm{P}=$ dengan pemutaran; $\mathrm{TP}=$ tanpa pemutaran

Hasil pegolahan data menunjukkan bahwa variabel independen konsentrasi inokulasi starter $1,5 \%$ dan waktu fermentasi 96 jam tanpa proses pemutaran memberikan hasil perolehan bioetanol yang optimum dengan persentase bioetanol mencapai 28,05\%. Untuk menganalisis adanya korelasi yang optimum antara kadar bioetanol dengan konsentrasi inokulasi starter dapat menggunakan persamaan regresi. Apabila nilai korelasi (R) semakin mendekati 1 maka korelasinya semakin signifikan. Hasil uji korelasi dapat dilihat pada Gambar 1; Gambar 2; Gambar 3 dan Gambar 4. 


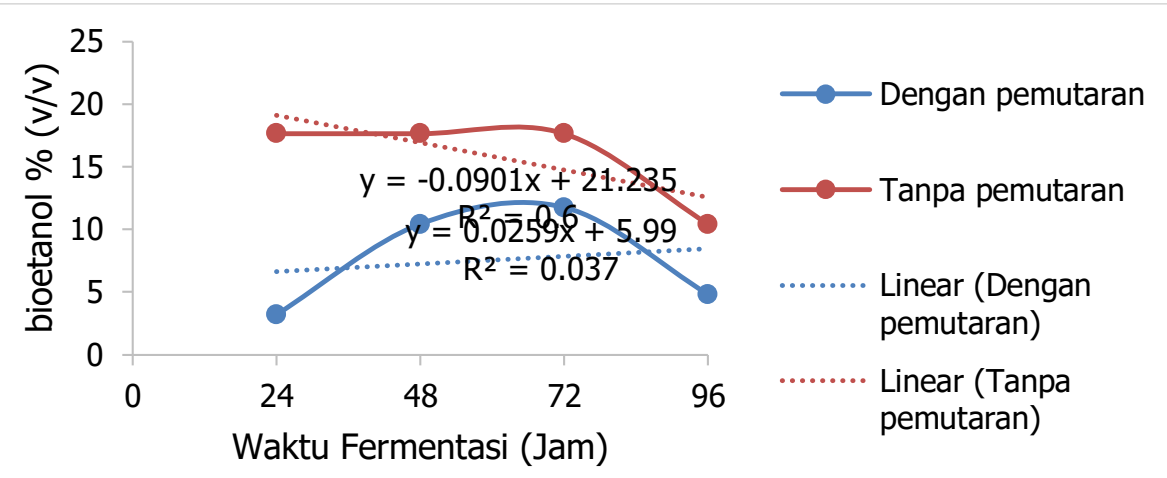

Gambar 1. Korelasi Kadar Bioetanol dengan Variasi Waktu Fermentasi pada Inokulasi Starter 1\%

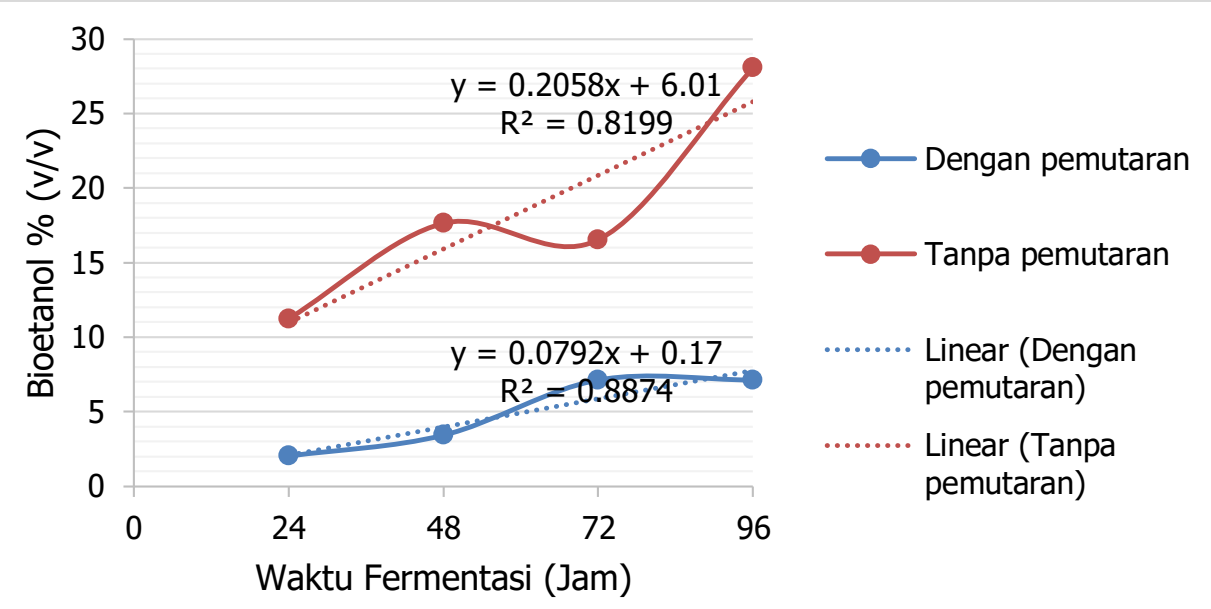

Gambar 2. Korelasi Kadar Bioetanol dengan Variasi Waktu Fermentasi pada Inokulasi Starter $1,5 \%$

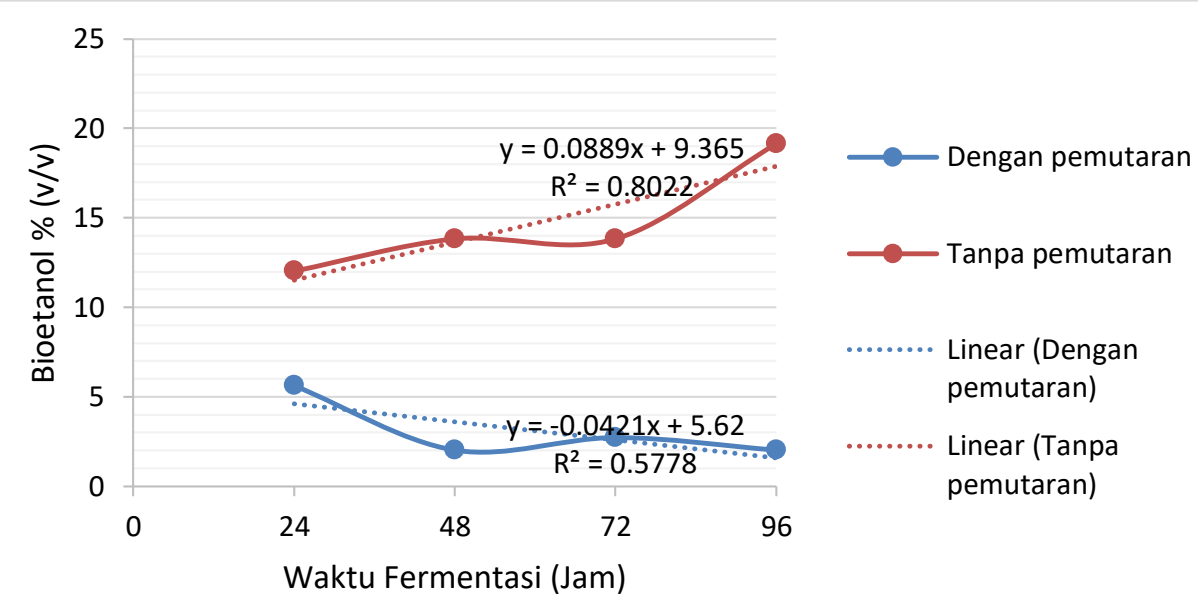

Gambar 3. Korelasi Kadar Bioetanol dengan Variasi Waktu Fermentasi pada Inokulasi Starter 2\% 


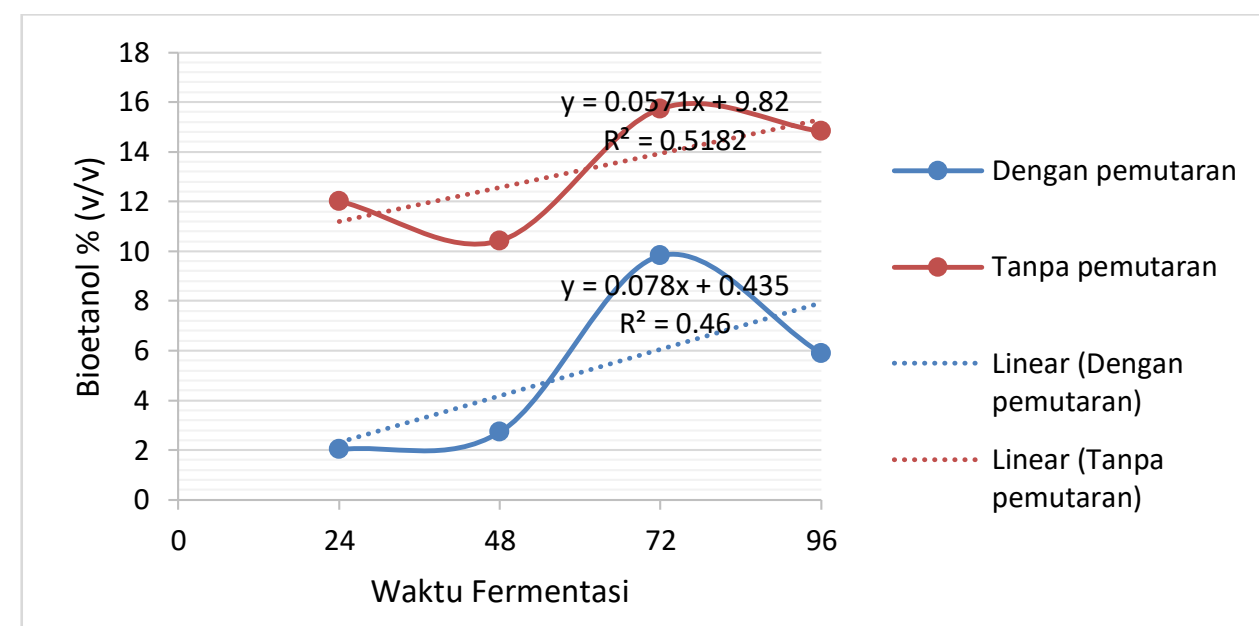

\section{Gambar 4. Korelasi Kadar Bioetanol dengan Variasi Waktu Fermentasi pada Inokulasi Starter $\mathbf{2 , 5 \%}$}

Waktu fermentasi adalah waktu yang dibutuhkan oleh Saccharomyces cerevisiae untuk mengubah atau memfermentasi glukosa menjadi bioetanol. Pada proses fermentasi, waktu fermentasi mempengaruhi kadar bioetanol yang dihasilkan (Nasrun dkk, 2015). Semakin lama waktu fermentasi maka semakin tinggi kadar bioetanol yang dihasilkan. Namun apabila terlalu lama nutrisi di dalam substrat akan habis sehingga Saccharomyces cereviceae tidak dapat memproduksi alkohol. Selain itu, pengaruh lingkungan juga sangat mempengaruhi perolehan kadar bioetanol seperti, suhu, pH dan udara (oksigen) (Prametha \& Legowo, 2013; Putra, 2017).

Waktu fermentasi dipengaruhi oleh beberapa faktor baik secara langsung maupun secara tidak langsung. Menurut Kunaepah (2008), faktor yang mempengaruhi fermentasi antara lain substrat, suhu, pH, oksigen dan mikroba yang digunakan. Substrat merupakan bahan baku fermentasi yang mengandung nutrisi yang dibutuhkan oleh mikroba untuk tumbuh maupun menghasilkan produk fermentasi (Azizah dkk, 2012). Substrat yang digunakan dalam penelitian ini adalah sari kulit nanas yang mengandung karbohidrat jenis fruktosa dan sukrosa. Gula-gula tersebut kemudian akan dikonversi menjadi bioetanol dengan bantuan Saccharomyces cereviceae karena adanya enzim invertase dan zymase. Hal ini sesuai dengan pernyataan Judoamidjojo \& Endang (1992), yang menyatakan bahwa Saccharomyces cereviceae dapat menghasilkan etanol yang berasal dari fermentasi glukosa. Glukosa akan diubah menjadi bentuk yang lebih sederhana oleh enzim invertase kemudian glukosa sederhana tersebut akan dikonversi menjadi etanol oleh enzim zymase.

Selain itu, pada penelitian ini ditambahkan urea sebagai nutrisi yang dibutuhkan oleh mikroba dalam memproduksi kadar bioetanol, urea digunakan sebagai sumber nitrogen yang dapat membantu dalam meningkatkan kadar bioetanol. Menurut Najah (2009), urea dalam air akan terhidrolisis menjadi ammonium dan karbondioksida. Dalam proses fermentasi, urea diperlukan sebagai sumber nitrogen untuk pertumbuhan dan meningkatkan aktifitas yeast. Dimana unsur nitrogen yang diperlukan berasal dari penguraian ammonium karbanat menjadi ammonium yang akan diambil nitrogennya saja, sedangkan unsur yang lain akan keluar bersama sisa metabolisme (Riza, 2016).

Lamanya waktu fermentasi juga berkaitan dengan pertumbuhan dari Saccharomyces cereviceae dan dapat digambarkan dengan kurva pertumbuhan yang menunjukkan masingmasing fase pertumbuhan. Ada 4 fase pertumbuhan yang meliputi fase adaptasi, fase 
tumbuh cepat, fase stasioner dan fase kematian. Fase adaptasi digambarkan dengan garis kurva dari keadaan nol kemudian sedikit ada kenaikan. Di dalam fase ini Saccharomyces cereviceae mengalami masa adaptasi dengan lingkungan dan belum ada pertumbuhan. Fase tumbuh cepat yang digambarkan dengan garis kurva yang mulai menunjukkan adanya peningkatan yang tajam. Pada fase ini Saccharomyces cereviceae mengalami pertumbuhan yang sangat cepat. Di dalam fase ini terjadi pemecahan gula secara besar-besaran guna memenuhi kebutuhan pertumbuhan Saccharomyces cereviceae. Hasil pemecahan gula oleh Saccharomyces cereviceae dalam keadaan anaerob menghasilkan bioetanol.

Fase stasioner yang digambarkan dengan garis kurva mendatar yang menunjukkan jumlah Saccharomyces cereviceae yang hidup sebanding dengan jumlah yang mati. Fase kematian digambarkan dengan penurunan garis kurva. Pada fase ini jumlah Saccharomyces cereviceae yang mati jumlahnya lebih banyak sampai akhirnya semua Saccharomyces cereviceae mati. Menurut Nasrun, dkk (2010) konsentrasi awal sel tertinggi adalah pada saat awal fase stasioner. Oleh karena itu, pada penelitian ini kultur starter yang digunakan untuk fermentasi bioetanol adalah Saccharomyces cereviceae pembentuk flok yang berumur 15 jam yaitu berdasarkan hasil kurva pertumbuhan dimana konsentrasi sel dianggap paling mak simal serta fase adaptasi sel terhadap medium fermentasi selanjutnya dapat dipercepat sehingga proses fermentasi berjalan lebih cepat. Fase kematian Saccharomyces cereviceae pembentuk flok tidak teramati pada kurva karena pengukuran sel menggunakan OD dimana sel yang terbaca merupakan total sel yang hidup dan mati. Pada penelitian ini, fasa lag atau fasa adaptasi tidak lagi ditemukan pada proses fermentasi. Hal ini dikarenakan adanya tahapan persiapan starter atau tahapan pengembangan inokulum.

Volume inokulum merupakan variabel yang paling berpengaruh dalam menghasilkan bioetanol, semakin besar volume inokulum maka akan semakin besar pula konsentrasi bioetanol yang didapat. Hal ini dikarenakan fase lag dipengaruhi oleh volume inokulum. Semakin besar inokulum maka semakin pendek fase lag yang terjadi, sehingga cepat mencapai fase eksponensial. Dengan kata pada fase ini mikroorganisme telah menyesuaikan diri dengan media fermentasi sehingga penimbunan sel berlangsung dengan waktu regenerasi yang cepat. Pertumbuhan pada fase eksponensial memberikan laju pertumbuhan mikroorganisme yang maksimum yang menghasilkan penimbunan sel yang besar dengan waktu regenerasi yang relatif cepat.

Pada waktu fermentasi lebih dari 48 jam konsentrasi sel yang didapatkan cenderung konstan bahkan ada yang menurun. Hal ini dikarenakan pertumbuhan mikroorganisme mencapai keadaan maksimum dan mikroorganisme yang aktif dan mati relatif seimbang yang disebut juga dengan fase stationer dan dilanjutkan dengan fase kematian. Kecenderungan konsentrasi bioetanol yang konstan bahkan menurun ini disebabkan oleh berkurangnya nutrisi pada medium serta semakin lama proses fermentasi menyebabkan banyak bioetanol yang telah terproduksi teroksidasi menjadi asam-asam organik dan $\mathrm{CO} 2$ yang merupakan senyawa inhibitor oleh mikroorganisme yang menyebabkan kematian pada mikroorganisme (Ahmad \& Antonius, 2010).

Menurut Kunaepah (2008), semakin lama waktu fermentasi maka jumlah mikroba semakin menurun dan akan menuju ke fase kematian karena alkohol yang dihasilkan semakin banyak dan nutrient yang ada sebagai makanan mikroba semakin menurun. Menurut Roukas (1996), penurunan bioetanol terjadi pada konsentrasi glukosa berlebih sebagai efek inhibisi substrat dan produk. Konsentrasi substrat yang terlalu tinggi mengurangi jumlah oksigen terlarut, walaupun dalam jumlah yang sedikit, oksigen tetap dibutuhkan dalam fermentasi oleh Saccharomyces cereviceae untuk menjaga kehidupan dalam konsentrasi sel tinggi. 
Perbedaan perolehan kadar bioetanol juga dapat disebabkan karena adanya perbedaan suhu. Pada proses pemutaran suhu meningkat sampai $40^{\circ} \mathrm{C}$ karena adanya energi kinetik yang ditimbulkan dari gesekan antara magnetic stirrer dan fermentor sehingga menimbulkan panas dan menyebabkan suhu meningkat, hal ini juga yang mengakibatkan proses fermentasi terganggu karena jika suhu tinggi akan mempercepat Saccharomyces cereviceae dalam memproduksi alkohol sehingga kadar bioetanol yang dihasilkan sangat rendah.

Peningkatan suhu sampai $40^{\circ} \mathrm{C}$ dapat mempertinggi kecepatan awal produksi etanol, tetapi produktivitas fermentasi secara keseluruhan menurun karena meningkatnya jumlah etanol menyebabkan terhambatnya pertumbuhan sel khamir. Suhu merupakan salah satu faktor penting dalam proses fermentasi. Reaksi terjadi secara eksoterm sehingga semakin lama suhu media fermentasi semakin tinggi seiring dengan meningkatnya aktivitas khamir memfermentasi glukosa. Adanya perlakuan dalam proses fermentasi yaitu proses pemutaran juga dapat mempengaruhi dalam perolehan kadar bioetanol.

Proses pemutaran merupakan suatu perlakuan dengan gerakan terinduksi terhadap suatu bahan di dalam fermentor sehingga dapat meningkatkan suhu. Jika suhu naik maka akan mempercepat laju reaksi karena partikel zat-zat meningkat sehingga memungkinkan semakin banyaknya tumbukan efektif yang menghasilkan perubahan. Menurut kurniawan dkk (2011), peningkatan kecepatan pemutaran akan menghasilkan arus yang lebih besar sehingga glukosa yang terdapat pada substrat tidak termanfaatkan dengan baik, sehingga menurunkan perolehan konsentrasi bioetanol. Akibatnya waktu kontak enzim yang dihasilkan oleh yeast dengan substrat lebih cepat sehingga glukosa yang tekonversi menjadi bioetanol sedikit.

Selain itu, keasaman atau $\mathrm{pH}$ juga dapat mempengaruhi pertumbuhan Saccharomyces cereviceae dalam memproduksi etanol. Menurut Roukas (1996), kisaran pertumbuhan Saccharomyces cereviceae adalah pada $\mathrm{pH}$ 3,5 - 6,5. Pada kondisi basa, Saccharomyces cereviceae tidak dapat tumbuh. Ditambahkan oleh Elevri dan Putra (2006), bahwa produksi etanol oleh Saccharomyces cereviceae paling maksimal dapat dicapai pada pH 4,5. Namun dalam proses fermentasi terjadi penurunan dan peningkatan $\mathrm{pH}$ karena di dalam proses fermentasi Saccharomyces cerevisiae selain menghasilkan etanol juga menghasilkan $\mathrm{CO} 2$ dan asam-asam organik. Perubahan $\mathrm{pH}$ dalam fermentasi disebabkan karena dalam aktivitasnya sel khamir selain menghasilkan etanol sebagai metabolit primer juga menghasilkan asam-asam organik seperti asam malat, asam tartarat, asam sitrat, asam laktat, asam asetat, asam butirat dan asam propionate sebagai hasil sampingan. Asam-asam ini dapat menurunkan $\mathrm{pH}$. Peningkatan $\mathrm{pH}$ dapat terjadi karena tumbuhnya bakteri lain dalam substrat fermentasi sari kulit nanas akibat terkontaminasi karena seringnya dibuka tutup sehingga bereaksi dengan udara.

\section{KESIMPULAN}

Dari hasil penelitian yang telah dilakukan dapat disimpulkan bahwa pada inokulasi starter $1,5 \%$ perolehan bioetanol mencapai optimum sebesar $28,05 \%$ pada waktu fermentasi 96 jam, kondisi tanpa pemutaran dengan koefisien korelasi 0,9054. Sedangkan pada inokulasi starter $1 \%$, $2 \%$ dan 2,5\% kondisi optimum tercapai pada waktu 72 jam, namun perolehan bioetanol $<28,05 \%$. 


\section{DAFTAR RUJUKAN}

Ahmad, T., \& Antonius, P. (2010). Pembuatan Bioetanol dari Kulit Nanas. Tugas Akhir. Universitas Sebelas Maret Surakarta.

Apriani, E. (2015) Pengaruh Rasio Urea dan NPK pada Proses Pembuatan Bioetanol dari Mahkota Nanas. http://eprints.polsri.ac.id/1967/ (diunduh 11 Maret 2019).

Azizah, N., Al-Baarri, N., Mulyani, S. (2012). Pengaruh Lama Fermentasi terhadap Kadar Alkohol, pH, dan Produksi Gas pada Proses Fermentasi Bioetanol dari Whey dengan Substitusi Kulit Nanas. Jurnal Aplikasi Teknologi Pangan, Vo.1 No.2, 72-77.

Judoamidjojo, M., \& Endang, M.A. (1992). Teknologi Fermentasi. Jakarta Rajawali Press.

Kunaepah, U. (2008). Pengaruh Lama Fermentasi dan Konsentrasi Glukosa terhadap Aktivitas Antibakteri, Polifenol Total dan Mutu Kimia Kefir Susu Kacang Merah. Tesis. Program Pasca Sarjana Universitas Diponegoro Semarang.

Loupatty, V.D. (2014). Pemanfaatan Bioetanol sebagai Sebagai Sumber Energi Alternatif Pengganti Minyak Tanah, Majalah BIAM, 10, 50-59.

Mandari, S., Yenie, E., Muria, S.R (2014). Pembuatan Bioetanol dari Kulit Nanas (Ananas Comosus.L) menggunakan Enzim Selulase dan Yeast Saccharomyces cerevisiae dengan Simultaneous Sacharificatian and Fermentation (SSF). Jurnal Online Mahasiswa Fakultas Teknik Universitas Riau.

Najah, N. (2009). Pengaruh Penambahan Nitrogen dan Waktu Fermentasi Terhadap Kadar Etanol Pada Proses Fermentasi Kulit Pisang Ambon Kuning (Musa paradisiaca Linn.).Skripsi. Program Studi Kimia. Fakultas Sains dan Teknologi. Universitas Islam Negeri Sunan Kalijaga. Yogyakarta.

Nasrun., Jalaluddin., Mahfuddhah. (2015). Pengaruh Jumlah Ragi dan Waktu Fermentasi terhadap kadar Bioetanol yang dihasilkan dari Fermentasi Kulit Pepaya. Jurnal Teknologi Kimia Unimal, 4, 1-10.

Prametha, N.M. \& Legowo, A.M.(2013). Pemanfaatan Susu Kadaluwarsa dengan Fortikasi Kulit Nanas untuk Produksi Bioetanol. Jurnal Aplikasi Teknologi Pangan. Vol 2, No. 1, 3035.

Putra, T.S., . (2017). Pemanfaatan Limbah Paduan Pucuk Tebu, Kulit Nanas dan Batang Jagung sebagai Energi Terbarukan Bioetanol, JTM, 5 No. 3, 35-45.

Rahman, N.A \& Setyawati, H. (2012). Peningkatan Kadar Bioetanol dari Kulit Nanas Menggunakan Zeolit Alam dan Batu Kapur. Jurnal Teknik Kimia, 6 No.2, 46-49.

Roukas, T. (1996). Continous Bioetanol Production from Non-Sterilized Carob Pod Extract by Immobilized Saccharomyces cereviceae on Mineral Kissiris Using A Tworeactor System. Journal Applied Biochemistry and Biotechnology, Vol 59, No. 3.

Riza, M. (2016). Pemanfaatan Limbah Kulit Ubi Kayu (Manihot utillisima Pohl.) dan Kulit Nanas (Ananas comosus L.) pada Produksi Bioetanol. The 3rd University Research Colloqium 2016. ISSN 2407-9189.

Sugiyono.(2010). Metode Penelitian Kuantitatif Kualitatif dan R\&D. Alfabeta 